\title{
ARE OPSONINS DISTINCT FROM OTHER ANTIBODIES ?*
}

\author{
LUDVIG HEKTOEN \\ (From the Memorial Institute for Infectious Diseases, Chicago.)
}

WRIGHT and Douglas first demonstrated that normal serum contains certain substances, called by them opsonins, which render various bacteria suceptible to phagocytosis by polynuclear leucocytes. Wright and his followers, Neufeld and Rimpau, as well as others have shown that the substances arising in response to immunization promote phagocytosis by a similar opsonic action upon the bodies that are taken up by the phagocytes. ${ }^{\text {I }}$

Whether this opsonic action is the property of antibodies with which we are already somewhat familiar, such as amboceptors and agglutinins, or whether opsonins are distinct and independent units in the serum, is an interesting and important question.

Before the exact interaction of serum and cells in phagocytosis had been made clear, Metchnikoff and his followers attributed the promotion of phagocytosis by immune serum to the so-called fixators, which in general are regarded as identical with Ehrlich's amboceptors. Quite recently Dean, ${ }^{2}$ from the results of the study of the effects of heat upon the opsonic power of normal and immune serum, has expressed the view that amboceptors may exercise the functions of opsonins, which consequently cannot be regarded as independent substances. Neufeld and Töpfer, ${ }^{3}$ however, as well as Barratt, ${ }^{4}$ hold that the opsonic substances for erythrocyteshemopsonins-that arise in animals on immunization with alien blood are distinct from the hemolytic amboceptors, because a serum might be lytic for certain corpuscles without being opsonic, and vice versa.

In the course of our work a number of facts have been brought out that seem to be of importance in regard to the question of the entity of the opsonins.

* Received for publication March 25, 1006.

II have discussed phagocytosis and opsonification in various phases in the Middleton-Goldsmith lecture of the New York Pathological Society, February 23, rgo6. (Jour. Am. Med. A ssoc, Igo6.)

- Proc. Roy. Soc., B, 1905, 76, p. 506, and Centralbl. f. Bakl., Abt. I, 1905, Ref. 37, p. 349.

3 Centralbl. f. Bakt., Abt. I, 1905, 38, Orig., p. 456.

${ }_{4}$ Proc. Roy. Soce, B, x905, 76, p. 524. 
In the first place I have shown ${ }^{1}$ that the opsonic effect of dog serum upon anthrax bacilli is practically destroyed, at most residual traces only being left, on heating the serum to $60^{\circ}$ to $62^{\circ} \mathrm{C}$., whereas the amboceptor for anthrax bacilli in dog serum is not appreciably affected by heating to $65^{\circ} \mathrm{C}$. for 30 minutes. This appears to indicate that the opsonin and the amboceptor in dog serum are distinct bodies with different degrees of resistance to heat, but of course it cannot be denied that the amboceptor might act as opsonin and that the opsonic function might be the first to be lost on heating. Hence it is necessary to examine into the conditions presented by other sera.

The serum of white rats is normally anthracidal, due to a thermostable substance that is neutralized by neutralization of the serum with oxalic acid. The same serum contains an opsonin for anthrax bacilli which, however, is not neutralized by oxalic acid. ${ }^{2}$

A somewhat analogous condition obtains in the serum of rabbits and goats immunized against the so-called virulent pseudodiphtheria bacilli, studied by Miss Hamilton in conjunction with Miss Horton. ${ }^{3}$ Here the bactericidal substance is also thermostable, and as yet in no way resolvable into amboceptor and complement. These sera also contain specific opsonins which differ in important points from the bactericidal substances.

While it cannot be asserted that the amboceptor nature of the opsonins in these instances is absolutely excluded, there is good reason to regard them as distinct substances.

Normal human serum, as well as other sera, contains opsonins for streptococci and pneumococci, but not any lytic amboceptors for these organisms, which grow freely in the sera. Besredka and Dopter ${ }^{4}$ applied the Bordet-Gengou method of fixation of the complement in order to learn whether the serum of scarlet-fever patients contains a special fixator (amboceptor) for any special streptococci, but in no one of seven cases could they demonstrate fixators for streptococci cultivated either from the patient furnishing the serum or from other sources. The Bordet-Gengou method is regarded by the French workers as a reliable method for demonstrating specific

\footnotetext{
IJour. Inject. Dis., 1906, I, p. I02. $\quad 3$ Jour. Infect. Dis., 1906, 1, p. 128.

- Horton, Jour. Infect. Dis., 1906, I, p. I10. 4Ann, de l'Inst. Pasteur, 1904, I8, p. 373.
} 
amboceptors in sera that are not bacteriolytic. ${ }^{\mathrm{I}}$ Now the serum of scarlet-fever patients contains as a rule considerable opsonin for streptococci as well as pneumococci, and consequently we may conclude that in this case there is no evidence to show that the opsonin is not a distinct substance.

Immunization with streptococci and with pneumococci has been shown by Neufeld and Rimpau and others to give rise to opsonins in the sera of the immune animals, but not, so far as we know, to the formation of specific amboceptors demonstrable by lysis of the organisms in question through the interaction of complement and amboceptor. It is true that Besredka maintains that he has demonstrated specific fixators in some antistreptococcus sera by means of the Bordet-Gengou phenomenon. Without entering on a discussion of the reliability of the method, concerning which I feel that there is reason for some doubt, it may be pointed out that, while Besredka noted that heated streptococci did not fix the complement as well as the unheated, yet heated streptococci are opsonized by human serum as readily as the unheated.

Greig Smith ${ }^{3}$ observed that agglutinating serum causes phagocytosis of typhoid bacilli which are not taken up by washed leucocytes in $\mathrm{NaCl}$ solution. I have found that normal serum is opsonic for typhoid bacilli, but not necessarily agglutinating. Naturally opsonized bacilli may be taken up in large numbers when in clumps, but mere clumping, as by vesuvin, safranin, etc., does not lead to phagocytosis (Greig Smith). In the case of other bacteria also, e. g., streptococci, pneumococci, anthrax bacilli, opsonification may be induced by various sera that have no agglutinative effect upon the particular bacterium in question.

The opsonic substances possess greater power to resist heat than do most of the complements with which we are familiar. Human

\footnotetext{
s Bordet and Gengou (Ann. de l'Inst. Pasteur, rgor, r5, p. 288) devised an ingenious method by which it is claimed that the presence of special fixators (amboceptors) may be demonstrated in sera that are not bacteriolytic. The serum to be tested is first heated and then mixed with a small quantity of fresh normal serum-complement-and bacterial emulsion. After standing for six hours at the room temperature red corpuscles treated with heated hemolytic serum are added. If there is no hemolysis, it is held to mean that the complement in the fresh serum which is suitable for lysis of properly prepared corpuscles has been absorbed by the bacteria by virtue of their having taken up special amboceptors present in the serum tested. This is the phenomenon of "fixation of the complement."

a Ann de l'Inst. Pașteur, 1904, 18, p. 363 .

3 Abstr. in Bull. de l'Inst. Pasteur, I906, 4, p. 44, from Proc. of Linnean Society of New South Wales, rgo5.
} 
serum, normal as well as that obtained from convalescents from typhoid fever, retains its opsonic action on typhoid bacilli after complete destruction of the complement by heat. For these and other reasons it is not likely that opsonic action is exercised by complements as that word is understood in general at present.

By way of summary the following facts, then, speak in favor of the conclusions that bacterio-opsonins are distinct from other antibodies:

I. Heat may destroy the opsonic power, or opsonin, of serum, leaving the lytic amboceptors intact.

2. Serum, normal as well as immune, may contain opsonin for a given organism but not, at least so far as is yet known, the proper amboceptor for that organism.

3. A serum may contain opsonin for a bacterium but'no agglutinin, and the opsonin may persist after the bacteriolytic complement has been destroyed by heat.

Strong evidence in favor of the view that opsonins constitute a distinct class of substances is furnished by the study of phagocytosis of red corpuscles.

As indicated already Neufeld and Töpfer regarded the opsonin for red corpuscles-hemotropic substance as they would call themproduced on immunization with goat blood as a distinct body, because hemolytic and agglutinating sera are not necessarily opsonic.

The sera of various animals contain amboceptors in fairly pronounced concentrations for a variety of heterologous erythrocytes, but it is only exceptionally that a trace of erythrocytic opsonin can be demonstrated in normal sera. Now it may be urged that normal amboceptors really carry opsonic powers, but that this has not been made evident because proper leucocytes have not been used as phagocytes. This objection is not without some force, because there is reason to believe that opsonic serum may subject erythrocytes as well as bacteria to phagocytosis by one kind of leucocyte but not by other kinds.

What may be learned from study of the serum of animals immunized with alien blood?

Barratt ${ }^{1}$ has observed that doves immunized with hen blood : Loc, cit. 
yield a serum which is strongly opsonic with respect to hen corpuscles, but not at all lytic. He also notes that various immune hemopsonic sera are devoid of agglutinative effect on the corresponding corpuscles. Barratt consequently believes in the entity of opsonin.

In the serum of rabbits immunized with goat corpuscles there develops the new power to lake goat corpuscles (amboceptors) and to render the corpuscles of various animals, but specifically those of the goat, susceptible to phagocytosis by dog and other leucocytes (opsonin). The immune rabbit serum, however, does not possess increased hemolytic or agglutinative power with respect to all these corpuscles. The immune amboceptor for goat corpuscles is readily activated by normal rabbit serum; consequently there is little reason to believe that the presence of amboceptors for other corpuscles cannot be demonstrated because of the lack of proper complement, and the most reasonable conclusion is that immune opsonin is distinct from the amboceptors; the more so in view of the fact that on several occasions I have been able to demonstrate the presence of opsonin in the serum in which heating to $70^{\circ} \mathrm{C}$. - the serum being undiluted -for one hour seemed to have destroyed completely the hemolytic amboceptor for goat corpuscles.

Furthermore, by means of absorption experiments, I have been able to separate the amboceptor from the opsonin for goat corpuscles in the serum of rabbits immunized with goat blood. First I determined that o:0125 c.c. of the particular serum at my disposal constitutes what may be called an adequate opsonic dose for 0.2 c.c. of a 5 per cent suspension of washed goat corpuscles, using 0.2 c.c. of a suspension of washed leucocytes (dog or guinea-pig) to furnish the phagocytes. An easily demonstrable phagocytosis of goat corpuscles now takes place within an hour after putting the mixtures in the incubator.* This amount of heated immune serum (0.0125 c.c.) also causes complete laking of 0.2 c.c. of a 5 per cent suspension of goat corpuscles when activated with 0.05 c.c. of normal rabbit serum. The amboceptor concerned in this laking may be removed completely by means of washed sheep corpuscles, the opsonin for

\footnotetext{
* It must be remembered that in these experiments it is not possible to determine degrees of phagocytosis with the same accuracy as when we use bacteria, the number of which taken up may be counted and averaged.
} 
the goat corpuscles being left behind. The complete experiment with the necessary controls is illustrated in Table $\mathbf{I}$.

TABLE $\mathbf{r}$.

Separation of Amboceptor and Opsonin for Goat Corpuscles in Serum of RabBit Immune to Goat BLOOD.

Immune serum $0 . \mathrm{I}+5$ per cent Washed Sheep Corpuscles 1.6 c.c. Centrifugate after One Hour at $37^{\circ} \mathrm{C}$.

I.YSIS.

Supernatant fluid o.2 (o.0125 im. ser.) $+5 \%$ washed goat corpuscles $0.2+$ normal rabbit serum 0.05 . . . . .

Immune serum 0.0125 in $\mathrm{NaCl}$ sol. $0.2+5 \%$ washed goat corpuscles 0.2 + normal rabbit serum 0.05 . . . . . . . .

$\mathrm{NaCl}$ sol. only $0.2+5 \%$ washed goat corpuscles $0.2+$ normal rabbit serum 0.05 . . . . . . . . . . . . . .

$\mathrm{NaCl}$ sol. only $0.2+5 \%$ sheep corpuscles treated as above with immune serum $0.2+$ normal rabbit serum 0.05 . . . .

$\mathrm{NaCl}$ sol. only $0.2+5 \%$ normal sheep corpuscles $0.2+$ normal rabbit serum 0.05 . . . . . . . . . . . . .

$$
\begin{aligned}
& =\text { No lysis } \\
& =\text { Complete lysis } \\
& =\text { No " } \\
& =\text { Complete " } \\
& =\text { Trace } \\
& =\text { Phagocytosis } \\
& = \\
& =\text { No " }
\end{aligned}
$$$$
\text { PHAGOCYTOSIS. }
$$

Supernatant fluid o.2 (o.0 25 im. ser.) $+5 \%$ washed goat corpuscles $0.2+$ susp. washed dog leucocytes. $\cdot$. $\cdot \cdot \cdot \cdot$

$\mathrm{NaCl}$ sol. only $0.2+5 \%$ sheep corpuscles treated as above with immune serum $0.2+$ susp. washed dog leucocytes . . . .

$\mathrm{NaCl}$ sol. only $0.2+5 \%$ normal goat corpuscles $0.2+$ suspension washed dog leucocytes.$$
\text { washed dog leucocytes. }
$$

TABLE 2.

Absorption of Opsonin in Serum of Rabbits Immune to Goat Blood by (I) Sheep Corpuscles AND (2) Goat Corpuscles,

I.

Immune Serum $0.05+5$ per cent Suspension of Washed Sheep Corpuscles 2.4 c.c. Centrifugate after One Hour at $37^{\circ} \mathrm{C}$.

Supernatant fluid 0.6 (0.0 25 of serum) $+5 \%$ susp. goat corpuscles $0.2+$ suspension dog leucocytes 0.2 . . . .

Supernatant fluid 0.6 (o.0 25 of serum) $+5 \%$ susp. sheep corpuscles $0.2+$ suspension dog leucocytcs 0.2 . . .

Immune serum 0.0125 in $\mathrm{NaCl}$ sol. $0.6+5 \%$ susp. sheep corpuscles $0.2+$ suspension dog leucocytes $0.2 . . . .=\mathrm{Good}$

$=$ Good phagocytosis

$=$ No $\quad$ "

$=\operatorname{Good}$ "

2.

Immune Serum $0.05+5$ per cent Suspension of Washed Goat Corpuscles 2.4 c.c. Centrifugate after One Hour at $37^{\circ} \mathrm{C}$.

Supernatant fluid 0.6 (o. or 25 of serum) $+5 \%$ susp. sheep corpuscles $0.2+$ suspension dog leucocytes 0.2 . . . .

Supernatant fluid $0.6(0.0125$ of serum $)+5 \%$ susp. goat corpuscles $0.2+$ suspension dog leucocytes 0.2 . . . .

Immune serum 0.0125 in $\mathrm{NaCl}$ sol. $0.6+5 \%$ susp. goat corpuscles $0.2+$ suspension dog leucocytes 0.2 . . . . = Marked “

Table I shows that sheep corpuscles absorb opsonin as well as amboceptors in the immune serum, and the question consequently arises whether there are two opsonins in the serum, one for goat 
corpuscles and one for sheep corpuscles, or whether the sheep corpuscles remove only a fraction of a single opsonin. Further absorption experiments show that while goat corpuscles in excess remove all the opsonins in the serum for both kinds of corpuscles, sheep corpuscles in excess appear to remove only opsonins peculiar to themselves, as shown in Table 2. This result indicates that immune opsonic serum may contain specific and group opsonins analogous to the specific and group agglutinins in the sera of animals immunized with certain bacteria. The further discussion of this phase of the subject must be postponed to some future time.

The facts, then, which indicate that the erythrocytic opsonins also are distinct substances are, in brief, the following:

r. Normal serum may contain hemolytic amboceptors but not hemopsonins.

2. Immune serum may contain opsonic substances but not amboceptors or agglutinins for the corpuscles in question.

3. By absorption methods the specific amboceptors in an immune serum may be separated from the specific opsonins.

4. The opsonic power of serum persists after the complement has been destroyed by heat.

Finally, in view of the principal facts brought forward, namely, that normal serum may possess lytic power but not opsonic, and vice versa; that immunization in some cases may give rise to opsonic substances, but not to lytic amboceptors or to agglutinins; and that the specific amboceptor has been separated from the specific opsonic substance in an immune serum, it may be concluded that the opsonic function of normal and immune serum is due to a distinct body for which opsonin is an apposite and convenient name. 